\title{
Bankacılık Sektöründe İşveren Marka İmajı: Fonksiyonel Fayda, Müşteri Odaklılık Ve Güvenilir Finansal İmajın Etkileri

\author{
(Employer Brand Image in Banking Sector: Effects of Functional Utility, Customer \\ Orientation and Reliable Financial Image)
}

\author{
Çağla Pınar BOZOKLU iDa \\ a Başkent Üniversitesi, Ankara, Türkiye. cutkug@hotmail.com
}

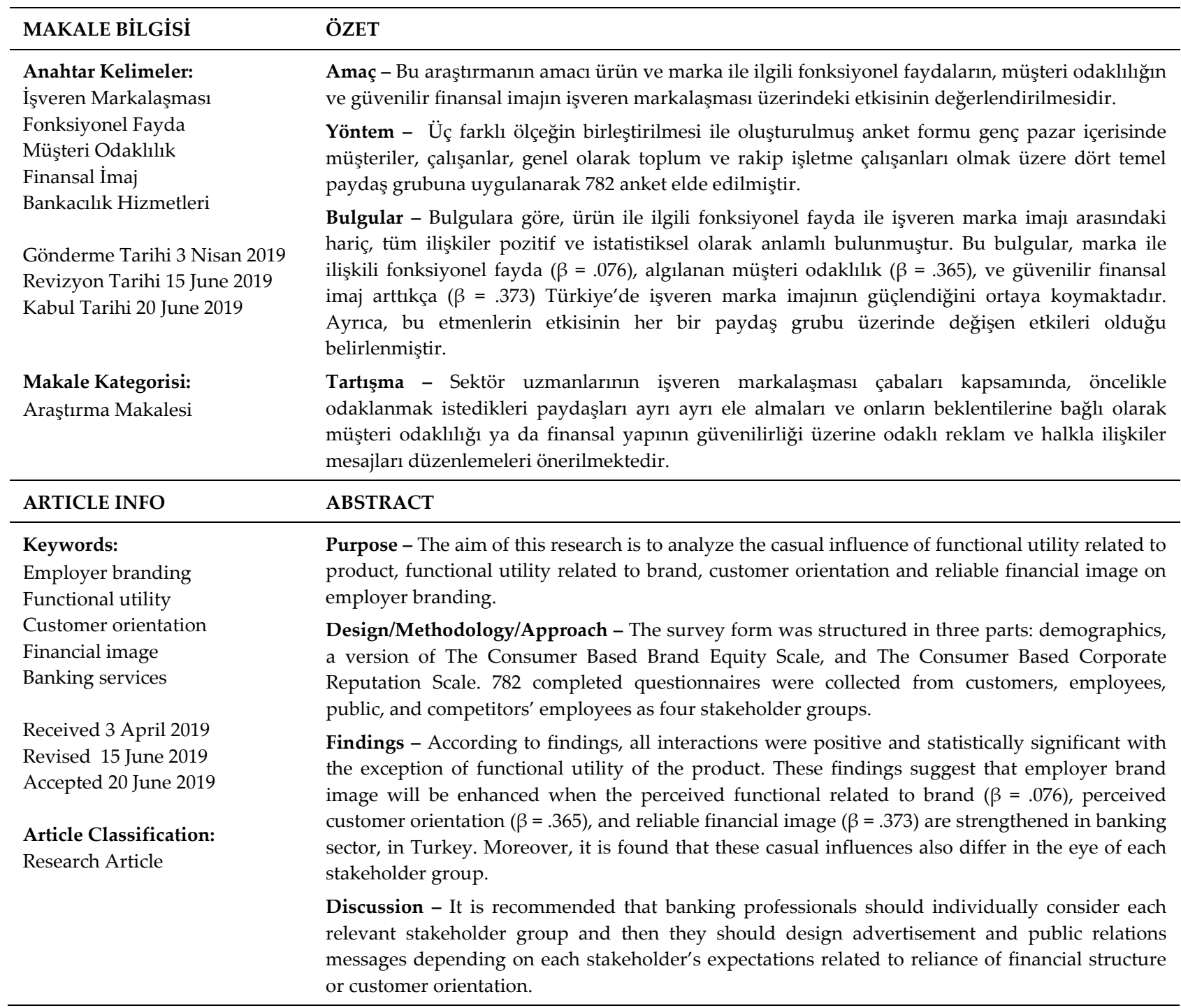

\section{GİRIŞ}

Dünyada 1960lardan sonra baskın bir role sahip olan hizmet işletmeleri, günümüzde kurumsal markalarını farklılaştırmak için itibar ile ilişkili çağrışımlara ve çeşitli kurumsal imaj boyutlarına odaklanan stratejiler geliştirmektedir. Hizmet işletmeleri marka yönetimine ilişkin kararlarını özellikle operasyonel ve kişilerarası işlemlerin bir arada yürütülmesinin ortaya çıkardığı karmaşıklık ile baş etmeye çalışırken vermektedir (Mosley, 2007). Bu durum, onların üretim işletmelerinden farklı olarak, ürün/marka önerilerinin imajına ek olarak, müşteri ilişkileri açısından da etkili kararlar almasını gerektirmektedir. 
Bu açıdan ekonomik sistemin en önemli parçalarından biri olan bankaların, kurumsal marka imajını çok boyutlu olarak ele alması ve bu boyutlara ilişkin ayırt edici stratejiler geliştirmesi gerekmektedir. Özellikle 1996 yılında konuşulmaya başlanmış olan işveren markalaşması kavramı, bankacılık sektöründe geleneksel stratejik yaklaşımları dönüştürecek bir etkiye sahiptir.

İşveren markalaşması ilk olarak “işe alan örgüt tarafından, yönetimin kolaylaştırılması ve önceliklere odaklanabilmesi amaciyla uyumlu bir çerçeve sunan istihdam ile sağlanan fonksiyonel, ekonomik ve psikolojik faydalar paketi" olarak tanımlanmıştır (Ambler ve Barrow, 1996); ancak daha sonraki yıllarda içsel markalaşma yaklaşımı ile kapsamı genişletilmiştir. Bu bakış açısı, örgütsel değerler ile çalışanları ve müşterileri içerecek şekilde bireysel değerleri uyumlulaştırması nedeniyle, içten dışarıya değer yaratımını sağlamaktadır (Manhnert ve Torres, 2007; Mosley, 2007). Bu noktada, çalışanların çabaları ile üretilen ürünlerin fonksiyonel faydasının, güvenilir finansal imajın ve müşteri odaklılığın işveren markalaşmasına etkisi olacağı düşünülmektedir. Örneğin yapılan birçok araştırma, kurumsal imajın müşterilerin ürünler hakkındaki değerlendirmeleri üzerinde doğrudan ve dolaylı etkileri olduğunu göstermektedir (Lai vd., 2010; Rehman ve Afsar, 2012). Çünkü bireyler kendileri ile benzer ya da olmak istedikleri benlik ile uyumlu marka kimlik özelliklerine karşı sempati duymaktadır (Hogg vd., 2000).

$\mathrm{Bu}$ araştırma, farklı beklentileri ve dolayısıyla farklı algılamaları olan dört temel paydaş grubunu temel alarak, ürün ve markanın fonksiyonel faydası, müşteri odaklılık ve güvenilir finansal imajın işveren markalaşmasındaki doğrudan etkisini analiz etmektedir. Müşteri, çalışanlar, genel olarak toplum ve rakip işletme çalışanlarından oluşan örneklem, aynı zamanda sektör uzmanları ve uzman olmayan kişiler olarak da ele alınabilmektedir. Sahip olunan sektörel bilgiye dayalı olarak bu etkileşimin değişeceği varsayılmaktadır. Ürüne ilişkin fonksiyonel fayda, markaya ilişkin fonksiyonel fayda ve güvenilir finansal imaj operasyonel stratejiler kapsamında ele alınırken; algılanan müşteri odaklılık kişilerarası iletişim stratejileri kapsamında ele alınmıştır. Bu doğrultuda işveren markalaşması, ürüne ve markaya ilişkin fonksiyonel faydalar, müşteri odaklılığı ile güvenilir finansal imaj kavramları açılandıktan sonra, araştırma modeli, yöntem ve bulgular sırasıyla sunulmaktadır.

\section{KAVRAMSAL ÇERÇEVE}

\section{1. İşveren Markalaşması}

Kurumsal imaj, müşterilerin belirli bir örgüt hakkında zihninde yer alan çok boyutlu algılaması olarak tanımlanabilmektedir (Rehman ve Afsar, 2012). Bu zihinsel iz düşüm, örgüt kültürü ve marka önerilerini içeren kurumsal kimliğinin farklı açılarını göstermektedir.

Bunlardan biri olan işveren marka imajı, kurumların insan sermayesine yönelik tutumunu marka kimliğinin bir parçası olarak kabul etmektedir (Martin vd., 2005; Mosley, 2007; Barrow ve Mosley, 2011). Bu alanda çalışan araştırmacılar, güçlü kurumsal marka imajına sahip işletmelerin sektördeki en yetkin çalışanları işe alabilen ve onları elinde tutabilen işletmeler olduğuna vurgu yaparak (Ambler ve Barrow, 1996; Ind, 1997,1998; Hart ve Murphy, 1998; Backhaus ve Tikko, 2004; Berthon vd., 2005; Carrington, 2007; Moroko ve Uncles, 2008), bu kavramın önemine değinmiştir.

İşveren markası ilk olarak Ambler ve Barrow (1996: 187) tarafından “işe alan örgüt tarafından, yönetimin kolaylaştırılması ve önceliklere odaklanabilmesi amacıyla uyumlu bir çerçeve sunan istihdam ile sağlanan fonksiyonel, ekonomik ve psikolojik faydalar paketi" olarak tanımlanmıştır. Burada temel amaç, üretkenliği artırmak, işe alımı ve bağlılığı geliştirmektir. Ancak tek faydası bu değildir. Bu bağlamda, marka değerlerinin çalışanlara aktarılması ve çalışanlarca da müşterilere iletilmesi işletmelerin sürdürülebilirliği açısından oldukça önemli bir noktadır (Hatch ve Shultz, 2001; Punjaisri vd., 2008). Bu sayede, hizmet markaları işletme, işletme çalışanları ve müşterilerden oluşan bir üçgen içerisinde içsel markalaşma adı ile iletişim kurucu etmen olarak faaliyet göstermektedir (Dall'Olmo Riley ve de Chernatony, 2000). İçsel markalaşma, örgütsel değerler ile çalışanlar ve müşterileri içerecek şekilde bireysel değerleri uyumlulaştırması nedeniyle, içten dışarıya değer yaratımını sağlamaktadır (Manhnert ve Torres, 2007; Mosley, 2007). Değerler arasındaki bu uyum ise, örgüt içerisinde çalışanların iş performansını artırırken, müşteriler ile iletişim içinde olan çalışanlar dolayısıyla ile müşteri odaklı stratejilere de fayda sağlamaktadır (Hoffman ve Woehr, 2006). Backhaus ve Tikko (2004: 503) da işveren markalaşmasının, çalışanların 
yetenekleri sayesinde işletme performansını artırdığını ileri sürmüştür. Benzer olarak, kaynak temelli stratejik yaklaşım örgütlerin kültürel karakteristiklerinin taklit edilemeyişleri nedeniyle rekabet avantajı sağlayan tek sürdürülebilir yetenek olduğunu vurgulamaktadır (Barney, 1991; Martin ve Hetrick, 2006). Marka vaadinin ve değerlerinin çalışanlar tarafından aktarılması tutarlı bir marka imajının ve çağrışımlarının dış paydaşlara iletilmesini kolaylaştırmaktadır (Bitner 1992; Berry 1995, 2000; Ind, 1998). Kısaca, yüksek etik standartlarla ilişkilendirilen güçlü bir işveren markası, müşteriler, rakip işletme çalışanları ve toplumun geneli gibi dış paydaşların gözünde hale etkisi yaratarak pozitif değerlendirmeler açığa çıkartacaktır.

Müşteriler ve toplumun geneli ile sektör çalışanları arasındaki en önemli fark ise, marka önerilerinin ve marka çağrısımlarının sahip olunan bilgi düzeyine göre yorumlanmasında ortaya çıkacaktır. Bu paydaş grupları arasında gözlemlenen bilgi asimetrisi sektörde faaliyette bulunan işletmelerin finansal bilgileri, ürün önerilerinin hukuki ve teknolojik altyapısı ile ilişkili olabilir. Çalışanlar iş hayatları boyunca bu konular bağlamında hem kendi işletmeleri hem de rakip işletmeler hakkında kapsamlı bilgiye sahip olmaktadır (Drucker, 2002; Barber ve Strack, 2005). Bu nedenle, sektöre yönelik marka tercihlerini daha rasyonel faktörlere dayalı olarak yapabilirler. Özellikle sektörel uzmanların bankacılık hizmetleri açısından finansal analiz yöntemlerine ve bankacılık düzenlemelerine daha hâkim olmaları, kurumsal marka imajı boyutlarını toplumun geneli ya da müşterilere kıyasla göreli olarak daha farklı yorumlamalarına neden olacaktır. Gatewood vd. (1993), marka değerinin önemli bir göstergesi olan işletme bilinirliliğinin (firm familiarity) çalışanların iş beklentileri açısından önemli bir etmen olduğunu tespit etmiştir.

Bunlara ek olarak, bankacılık sektöründe yapılmış kurumsal marka araştırmaları incelendiğinde, yazarların genç pazar bölümüne ilişkin araştırmaların yapılmasını önerdiği görülmektedir. Özellikle Y kuşağının nüfus dağılımda geniş yer kaplaması ve tüketim alışkanlıkları açısından farklılık göstermesi nedeniyle gelecekteki araştırmaların örneklemlerinin buna göre yapılandırılması tavsiye edilmektedir (Foscht vd., 2009). Teknolojiye olan yatkınları, dijital bankacılık uygulamalarına hâkim olmalarına ve bu hizmetleri tercih etmelerine neden olmaktadır.

Negara Bankası (Malezya) 2008 Yılı Yıllık Raporuna göre, finansal hizmetler kapsamında erişilebilirlik, cevap yetersizliği, anlayış eksikliği, fon sağlamada gönülsüzlük, zayıf şube hizmetleri, düşük iş bitirme süresi genç kuşak açısından en önemli konular olarak tespit edilmiştir (Bank Negara Malaysia, 2008). Ancak daha iyi bir itibarın ve marka imajının banka tercihinde önemli olduğunun bulunması nedeniyle (Tank ve Tyler, 2005), kurumsal marka imajı boyutlarına yönelik iyileştirmelerin bu sorunları çözmekte faydalı olacă̆ı düşünülmektedir.

\subsection{Algılanan Fonksiyonel Faydanın, Güvenilir Finansal İmajın ve Müşteri Odaklılığın İşveren Markalaşmasına Etkileri}

Minkiewicz vd.'ne (2011) göre, kurumsal imaj müşterilerin algıladığı değer ile pozitif ilişkilidir. Ancak paydaşların beklentileri gerçekçi olmayan marka önerileri nedeniyle gerçekleşmiyor ise, paydaşların tatminsizliği kaçınılmazdır. Son dönemlerde işletme satın almaları ya da işletme evlilikleri nedeniyle ulus ötesi bankaların ortaya çıkması, rekabetin daha da kızışmasına neden olmuştur. Bu noktada, bankacılık hizmetlerinin başarısı, paydaşlarca algılanan ürün faydası, itibar ve marka imajına dayanmaktadır (Rehman ve Afsar, 2012; İsmail vd., 2006; Al-Hawari ve Ward, 2005).

Algılanan değer kavramı kapsamında bazı araştırmacılar tek boyutlu yaklaşımı tercih etse de (Cronin vd., 1997; Patterson ve Spreng, 1997; McDougall ve Levesque, 2000), geçerlilik sorunlarından kaçınmak nedeniyle çoğu yazar çok-boyutlu yaklaşımı tercih etmektedir (Hunt, 1976; Woodruff ve Gardial, 1996; Grönroos, 1997; Grewal vd., 1998; Sweeney vd., 2001). Özellikle hizmetlerin algilanan faydasının ölçülmesinde çok boyutlu yaklaşım hem operasyonel stratejilerin, hem de kişilerarası iletişime dayalı stratejilerin değerlendirilmesini sağlaması nedeniyle tavsiye edilmektedir (Ravald ve Grönroos, 1996; Grönroos, 1997; Kandampully ve Duddy, 1999; Dwyer ve Tanner, 2002; Eggert and Ulaga, 2002). Vazquez vd. (2002) fonksiyonel fayda kavramını ürün ile ilişki fonksiyonel fayda ve marka ile ilişkili fonksiyonel fayda olarak ikiye ayırmaktadır. Ürün ile ilişkili fonksiyonel fayda kapsamında konfor, güvenlik ve dayanıklılık özellikleri yer alırken; markaya ile ilişkili fonksiyonel faydalar bireylerin ihtiyaç duyacağı garanti özelliğini içermektedir. 


\section{Ç. P. Bozoklu 11/2 (2019) 1103-1117}

Bankacılık hizmetlerinde çalışanların iletişim yetenekleri, uygulamalara ilişkin bilgi birikimleri, problem çözme yetenekleri, müşterilerin konfor ve güvenlik ihtiyaçlarını karşılamada etkili olana fonksiyonel faydalar kapsamında değerlendirilebilir. Heskett vd.'nin (1997) belirttiği gibi, çalışanlar ile müşteriler arasındaki etkileşim algılanan hizmet kalitesini etkilemektedir. Mobil ve internet bankacılığı sistemlerinin yürütülen işlemeler sırasında sağladı̆̆ı doğruluk, hız, konfor, güvenlik vb. faydalar oldukça önem taşımaktadır. Türkyilmaz ve Özkan (2007) yaptı̆̆ı araştırma sonrasında bankalara güven, bağlılık, verimli ve doğru iletişim, hızlı ve yetkin teslimat hizmetleri, etkin çatışma yönetimi ve iyileştirilmiş müşteri ilişkileri kalitesi üzerine yoğunlaşmalarını önermiştir. Buna bağlı olarak;

$\mathrm{H}_{1}$ : Ürün ile ilişkili fonksiyonel faydanın işveren marka imajı üzerinde pozitif ve doğrudan bir etkisi vardır.

İşletmeler ürünlerini kurumsal marka şemsiyesi altında markalayarak bağlı önerilerinin garantisini güçlendirebilmektedir (Dowling, 2006; Aaker, 2008; Bonini, Court, ve Marchi, 2009). Özellikle internet bankacıllı̆ı hem maliyetleri düşürmekte hem de kurumsal marka güvencesi altında dijital finansal işlemler yapılmasını sağlamaktadır. Kuisma, Laukkanen, ve Hiltunen (2007), internet bankacılığına yönelik fonksiyonel ve psikolojik risk algılamaları nedeniyle bir direnç olduğunu belirtmiş̧tir. Bu kapsamda;

$\mathrm{H}_{2}$ : Marka ile ilişkili fonksiyonel faydanın işveren marka imajı üzerinde pozitif ve doğrudan bir etkisi vardır.

Müşteri odaklılığıı, ürünlerin/hizmetlerin algılanan faydasına dayalı olarak müşteri taleplerinin karşılamasını sağlar (Narver ve Slater, 1990; La ve Kandampully, 2004;). Genellikle hizmet kâr zinciri olarak adlandırılan, tatmin olmuş çalışanlar, tatmin olmuş müşteri ve pozitif işletme sonuçları arasında pozitif yönlü güçlü bir ilişki bulunmaktadır. Zameer vd.'ne (2015) göre esnek karar alma ve çalışan yeteneği özellikle bankacılık hizmetlerinde müşteri memnuniyeti üzerinde etkilidir. Oly Ndubisi ve Koh Wah (2005) ile Khan ve Kadir (2011) hizmetin sunumu sırasında çalışan çabalarının müşteri memnuniyetini arttırdığını tespit etmiştir. Bu nedenle;

H3: Müşteri odaklılığın işveren marka imajı üzerinde pozitif ve doğrudan bir etkisi vardır.

Müşteriler, çalışanlar ve yatırımcılar gibi paydaşlar, pozitif ve güçlü imajı olan markaları tercih ederek bankacılık hizmetlerinin doğasından kaynaklanan finansal risklerden korunmak isterler. Örneğin, Pakistan'da müşterilerin banka tercihini etkileyen en önemli faktör finansal istikrar olarak tespit edilmiştir (Javed, 2005). Bazı araştırmacılar güçlü işveren marka imajının bir boyutu olduğu yüksek kurumsal itibarın belirli bir risk oranı için daha yüksek getiri sağladığını, hisse senedi değerini yükselttiğini ve daha tatmin edici kâr oranları sağladığını tespit etmiştir (Vergin ve Qoronfleh, 1998; Filbeck ve Preece, 2003; Rose ve Thomsen, 2004). Buna bağlı olarak;

H4: Güvenilir finansal imajın işveren marka imajı üzerinde pozitif ve doğrudan bir etkisi vardır.

\section{YÖNTEM}

\subsection{Araştırma Modeli}

$\mathrm{Bu}$ araştırmanın amacı ürün ve marka ile ilişkili fonksiyonel faydanın, algılanan müşteri odaklılığın ve güvenilir finansal imajın işveren markalaşması üzerindeki nedensel etkisini analiz etmektir. Ayrıca bu nedensel etkinin ilgili paydaş grubuna göre değişeceği düşünülmektedir. Araştırmanın bir kısıtı olarak algılanan sembolik fayda banka hizmetlerinin temelde finansal risk içermesi nedeniyle araştırma kapsamı dışında bırakılmıştır. Araştırma hipotezlerine bağlı olarak kurulan denklem aşağıdaki gibidir:

$$
\ddot{\mathrm{II}} \dot{I}_{\text {Imajl }}=\beta_{0}+\beta_{1}\left(F F_{\text {Ürün }}\right)+\beta_{2}\left(F F_{\text {Marka }}\right)+\beta_{3}(M O)+\beta_{4}(G F)+e
$$

İं $\dot{I m a j l}_{l}$ : İşveren marka imajı

$F F_{\text {Ürün }}$ Ürün ile ilişkili fonksiyonel fayda

$F F_{\text {Marka }}$ : Marka ile ilişkili fonksiyonel fayda

MO: Müşteri odakl1lı̆̆1

GF: Güvenilir finansal imaj 


\subsection{Evren ve Örneklem}

Araştırma süresinde 846 katılımcıya ulaşılmış, ancak kontrol sorularına verilen yanlış cevaplar ve eksik verileri olan 64 anket formunun çıkartılması ile 782 anket ile sonlandırılmıştır. Katılımcıların yer aldıkları paydaşlara göre bilgisi ise Tablo 1'de sunulmaktadır.

Tablo 1. Örneklemde yer alan paydaşlar ve bankalar

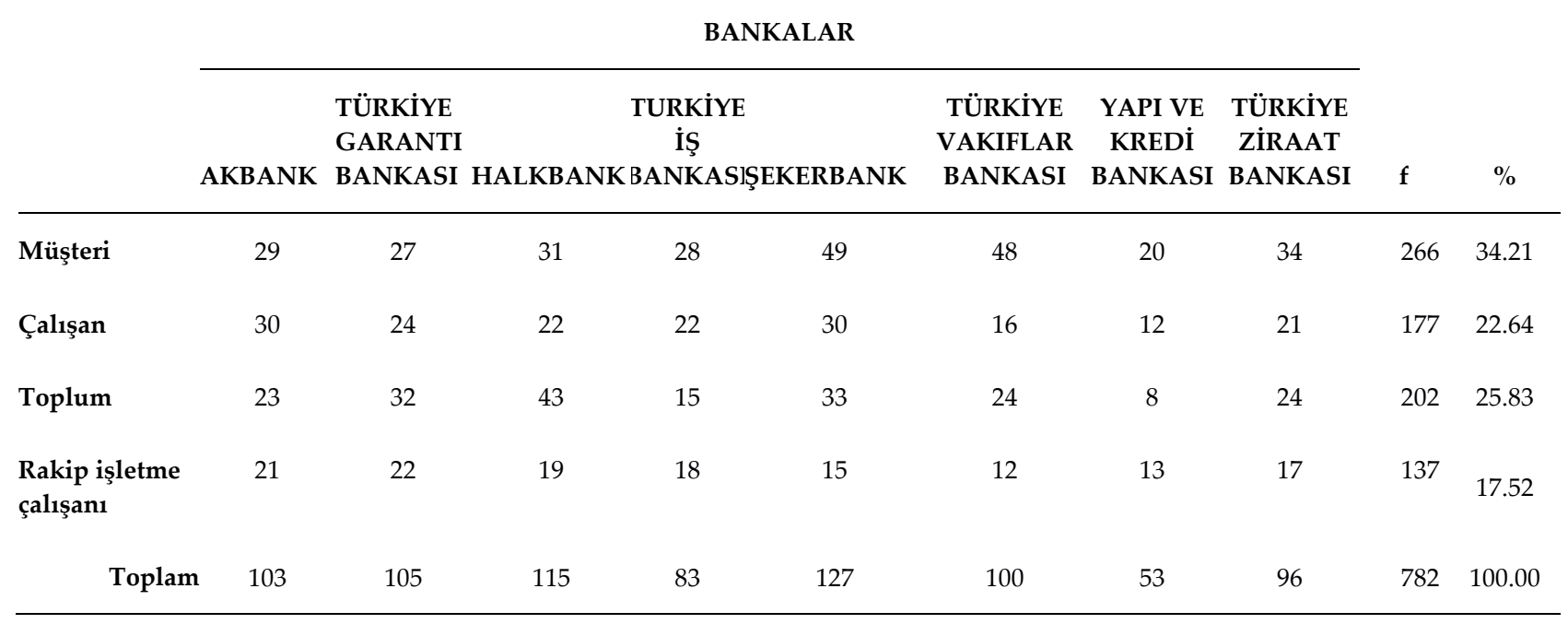

\subsection{Veri Toplama Araçları}

Anket üç bölümden oluşmaktadır. Birinci bölümde, katılımcıların cinsiyeti, yaşı, medeni durumu, eğitim durumu, gelir durumu, çalışıp çalışmadığı ve hangi paydaş grubunda olduğu gibi demografik özellikleri sorulmuştur. İkinci bölümde, Vazquez vd. (2002) tarafından geliştirilmiş Müşteri Odaklı Marka Değeri Ölçeği'nin bankacılık hizmetleri için uygun olan bir versiyonu kullanılmıştır. Bu ölçekte kullanılan maddeler (5’li Likert) bankacılık sektöründe etkili olan etmenleri ortaya koyan bazı ulusal yayınlardan yararlanılarak geliştirilmiştir (ör. Yılmaz vd., 2007; Cebeci ve Çabuk, 2016; Yılmaz,). Üçüncü bölümde ise, Walsh ve Beatty (2007) tarafından geliştirilmiş Müşteri Odaklı Kurumsal İtibar Ölçeği (5’li Likert) kullanılmıştır. Bu ölçek, "müşteri odaklılık", "iyi işveren", "güvenilir ve finansal açıdan güçlü işletme", "ürün kalitesi" ile "sosyal ve çevresel sorumluluk" olmak üzere beş temel kurumsal imaj boyutundan oluşmaktadır. Her iki ölçek de çeşitli ülkelerde ve kültürlerde yaygın olarak kullanılmış, geçerliliği ve güvenilirliği kabul görmüş ölçeklerdir. Yine de her biri için geçerlilik ve güvenirlik testleri yapılmış ve sonuçları bulguların analizi başlığı altında sunulmuştur.

\section{BULGULAR}

\subsection{Demografik Bilgiler}

Katılımcıların demografik istatistikleri Tablo 2'de gösterilmektedir. Bulgulara göre, katılımcıların \%48,33'ü kadınken, \%51,67'si erkektir. Katılımcıların yarısından fazlası $(\% 61,12)$ çalışmaktadır ancak sadece bir kişi çalışma durumuna ilişkin bilgiyi paylaşmamıştır. Katılımcılar çoğunlukla $(\% 85,8) 18$ ile 42 yaş aralığında yer almaktadır. Bunların \%40'ı özellikle 18-25 yaş grubunda yer alan gençlerden oluşmaktadır. Örneklemin neredeyse hepsi $(\% 96,62)$ en az lise mezunudur. Araştırma boyunca 103 Akbank, 105 Türkiye Garanti Bankası, 115 Halkbank, 83 Türkiye İş Bankası, 127 Şekerbank, 100 Türkiye Vakıflar Bankası, 53 Yapı Kredi Bankası ve 96 Türkiye Ziraat Bankası paydaşı olmak üzere toplam 782 kişiye ulaşılmıştır. 
Tablo 2. Demografik Bilgiler

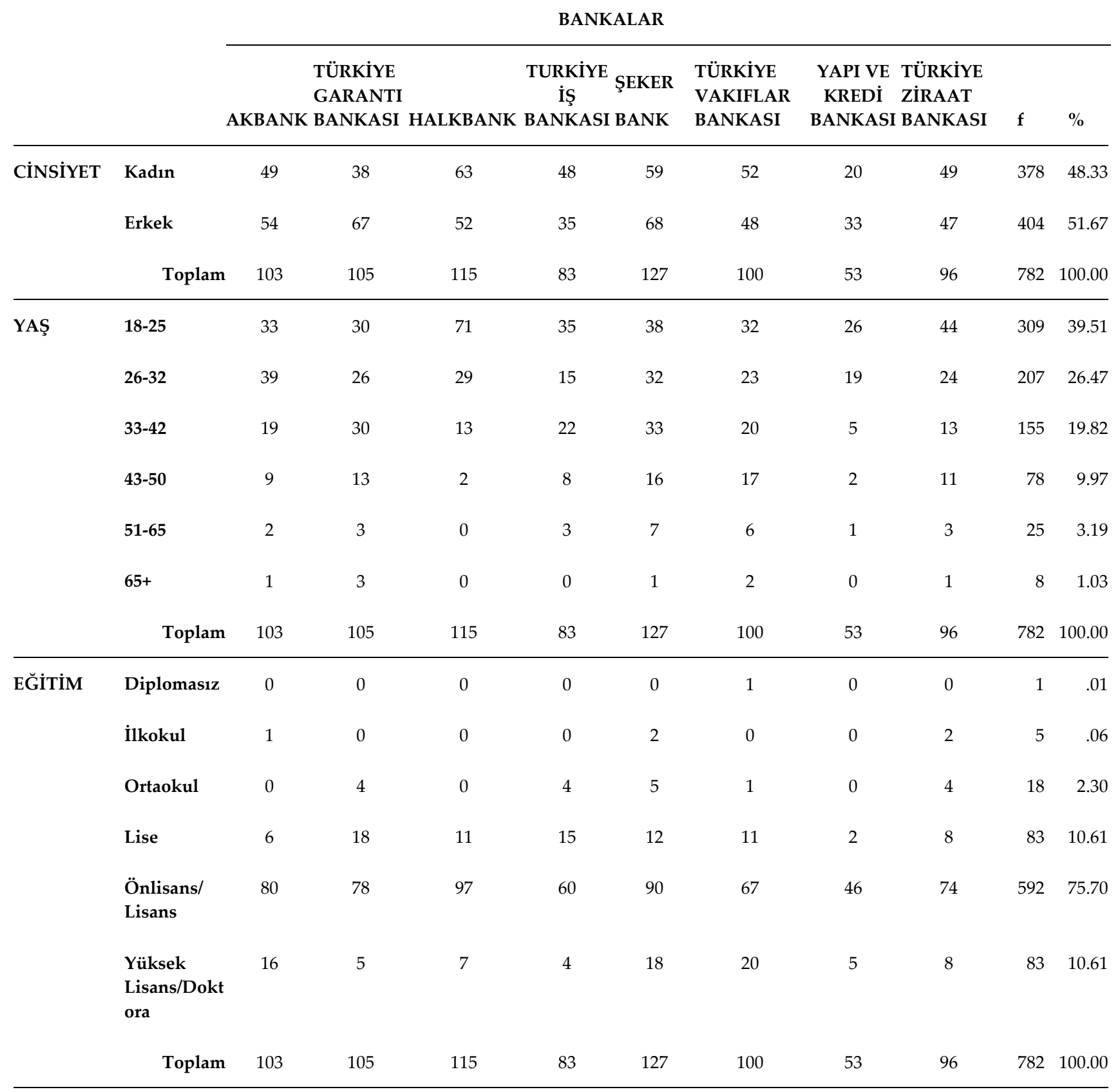

\subsection{Geçerlilik ve Güvenirlik Analizleri}

Güvenirlik testi bulguları Tablo 3'de sunulmaktadır. Madde toplam istatistiklerine bağlı olarak, Müşteri Odaklı Marka Değeri Ölçeği'nde kullanılan "X bankası ile yaptığım işlemlerde kendimi gergin hissederim" ifadesine ait dördüncü madde çıkartılmıştır. Bu sayede ürün ile ilişkili fonksiyonel fayda alt boyutuna ait Cronbach Alpha değeri 0,627'den 0,797'ye yükselmiştir. Tüm değişkenlere ait boyutların Cronbach Alpha değerleri eşik değer olan 0,70 'den büyük olması nedeniyle ölçeklerin güvenilir olduğuna kanaat getirilmiştir (Nunnally ve Bernstein, 1994; Hair vd., 2010). 


\section{Ç. P. Bozoklu 11/2 (2019) 1103-1117}

Tablo 3. Güvenirlik İstatistikleri

\begin{tabular}{lll}
\hline Ölçek & Boyut & Cronbach Alpha \\
\hline Marka Değeri & Ürün ile İlişkili Fonksiyonel Fayda & .797 \\
& Marka ile İlişkili Fonksiyonel Fayda & .867 \\
\hline Kurumsal İtibar & İyi İşveren & .913 \\
& Müşteri Odaklılık & .922 \\
& Güvenilir ve Finansal Açıdan Güçlü & .927 \\
& İşletme & \\
\hline
\end{tabular}

İkincil olarak, ölçeklerin geçerliliğini test etmek amacıyla faktör analizi yapılmıştır. Buna göre Ürün ile İlişkili Fonksiyonel Fayda Ölçeği için Barlett testi anlamlılık düzeyi 0,000, KMO değeri 0,788'dir. Tüm faktörlerin yükleri 0,665 ile 0,821 arasında değer almaktadır. Geliştirilen maddeler toplam varyansın $\% 55,80$ 'nini açılamaktadır.

Marka ile İlişkili Fonksiyonel Fayda Ölçeği için Barlett testi anlamlılık düzeyi 0,000, KMO değeri 0,733’dir. Tüm faktörlerin yükleri 0,876 ile 0,906 arasında değer almaktadır. Geliştirilen maddeler toplam varyansın \%79,03'ünü açılamaktadır.

Müşteri Odaklılığı Ölçeği için Barlett testi anlamlılık düzeyi 0,000, KMO değeri 0,898'dir. Tüm faktörlerin yükleri 0,761 ile 0,897 arasında değer almaktadır. Geliştirilen maddeler toplam varyansın \%72,506'sını açıklamaktadır.

Güvenilir ve Finansal Açıdan Güçlü İşletme Ölçeği için Barlett testi anlamlılık düzeyi 0,000, KMO değeri 0,931'dir. Tüm faktörlerin yükleri 0,805 ile 0,855 arasında değer almaktadır. Geliştirilen maddeler toplam varyansın \%69,605'ini açıklamaktadır.

İyi İşveren Ölçeği için Barlett testi anlamlılık düzeyi 0,000, KMO değeri 0,925'dir. Tüm faktörlerin yükleri 0,747 ile 0,840 arasında değer almaktadır. Geliştirilen maddeler toplam varyansın \%65,802'ini açılamaktadır.

\subsection{Korelasyon Testi ve Tanımlayıcı İstatistikler}

Değişkenlerin birbiriyle ilişkisi düzeyini ve ilişki yönünü açıklamak amacıyla Pearson korelasyon testi yapılmıştır. Tablo 4 korelasyon katsayılarını ve tanımlayıcı istatistikleri vermektedir. Buna göre, tüm değişkenler arasında güçlü ve pozitif yönlü ilişki tespit edilmiştir. Ürün ile ilişkili fonksiyonel fayda maddelerinin ortalaması 3,35; marka ile ilişkili fonksiyonel fayda maddelerinin ortalaması 3,53, müşteri odaklılığı maddelerinin ortalaması 3,61, güvenilir ve finansal açıdan güçlü işletme maddelerinin ortalaması 3,59 iken, iyi işveren boyutuna ait maddelerin ortalaması 3,52 olarak bulunmuştur. Buna ek olarak, bankaların işveren imajları arasında istatistiksel açıdan anlamlı bir farklılık olup olmadığı test edilmiş, ancak böyle bir farklılık tespit edilememiştir.

Tablo 4. Korelasyon Testi Bulguları

\begin{tabular}{ccccccc}
\hline $\mathrm{n}=782$ & ÜFF & MFF & MO & İ & GF \\
\hline ÜFF & 1 & $0,810^{* *}$ & $0,694^{* *}$ & $0,676^{* *}$ & $0,698^{* *}$ \\
MFF & $0,810^{* *}$ & 1 & $0,733^{* *}$ & $0,709^{* *}$ & $0,710^{* *}$ \\
MO & $0,694^{* *}$ & $0,733^{* *}$ & 1 & $0,790^{* *}$ & $0,706^{* *}$ \\
İ & $0,676^{* *}$ & $0,709^{* *}$ & $0,790^{* *}$ & 1 & $0,787^{* *}$ \\
GF & $0,698^{* *}$ & $0,710^{* *}$ & $0,706^{* *}$ & $0,787^{* *}$ & 1
\end{tabular}

ÜFF: Ürün ile İlişkili Fonksiyonel Fayda; MFF: Marka ile İlişkili Fonksiyonel Fayda; MO: Müşteri Odaklılı̆̆ı i İ: İyi İşveren; GF: Güvenilir ve Finansal Açıdan Güçlü İşletme ${ }^{* *} \mathrm{p}<0,001$ 


\subsection{Regresyon Analizleri}

\subsubsection{Temel Araştırma Modelinin Testi}

Değişkenler arasındaki ilişki seviyesine bağlı olarak, IBM SPSS Statistics 25 programı kullanılarak çoklu regresyon analizi yapılmıştır. Tablo 5'de sunulan model özetine göre, ürün ile ilişkili fonksiyonel faydanın, marka ile ilişkili fonksiyonel faydanın, müşteri odaklılığının ve güvenilir finansal imajın, işveren marka imajı üzerinde doğrudan pozitif yönlü bir etkisi olduğu varsayılmıştır. Sonuçlara göre, değişkenlerin işveren marka imajındaki toplam varyansın \%73,2' sini açıkladığı görülmektedir (adjusted $R^{2}=0,732 ; \mathrm{F}=535.095, \mathrm{df}=$ $4, \mathrm{p}<0,001)$.

Tablo 5. Model Özeti

\section{Model Özeti}

\begin{tabular}{cccccc} 
Model & $\mathbf{R}$ & $\boldsymbol{R}^{2}$ & $\begin{array}{c}\text { Düzeltilmiş } \\
\boldsymbol{R}^{2}\end{array}$ & SE & Durbin-Watson \\
\hline 1 & $0,856^{\mathrm{b}}$ & 0,733 & 0,732 & 0,41407 & 1,750
\end{tabular}

${ }^{a}$ Bağımlı Değişken: İşveren Marka İmajı ${ }^{b}$ Göstergeler: (Sabit katsayı), ürün ile ilişkili fonksiyonel fayda, marka ile ilişkili fonksiyonel fayda, müşteri odaklılığı, güvenilir finansal imaj

Tablo 6'da görüldüğü gibi, ürün ile ilişkili fonksiyonel fayda haricinde diğer bağımsız değişkenler kapsamında kurulan ilişkiler pozitif yönde, istatistiksel olarak anlamlıdır. Buna ek olarak, VIF değerleri önerilen eşik değerin (5) altında olması nedeniyle çoklu doğrusallık sorunun olmadığını da göstermektedir. Bu nedenlerden ötürü H2, H3, H4 kabul edilirken, H1 reddedilmiştir (Hair, 2010). Bu bulgulara göre, marka ile ilişkili fonksiyonel fayda $(\beta=0,076)$, algılanan müşteri odaklılık $(\beta=0,365)$ ve güvenilir finansal imaj $(\beta=$ $0,373)$ arttıkça, işveren marka imajı güçlenmektedir.

Tablo 6. Regresyon Analizi

\begin{tabular}{|c|c|c|c|c|c|c|c|}
\hline \multirow[b]{4}{*}{ Model } & \multicolumn{5}{|c|}{ Katsayılar } & & \\
\hline & \multicolumn{5}{|c|}{ Standartlaştırılmamış Standartlaştırılmı } & \multirow{2}{*}{\multicolumn{2}{|c|}{$\begin{array}{l}\text { Doğrusallık } \\
\text { İstatistikleri }\end{array}$}} \\
\hline & & yılar & ş Katsayılar & & & & \\
\hline & $\boldsymbol{\beta}$ & SE & $\boldsymbol{\beta}$ & $\mathbf{t}$ & $\mathrm{p}$ & Tolerans & VIF \\
\hline (Sabit Katsayı ) & 0,488 & 0,071 & & 6.915 & 0,000 & & \\
\hline $\begin{array}{l}\text { Ürün ile ilişkili fonksiyonel } \\
\text { fayda }\end{array}$ & 0,030 & 0,032 & 0,031 & .931 & 0,352 & 0,306 & 3,266 \\
\hline $\begin{array}{l}\text { Marka ile ilişkili } \\
\text { fonksiyonel fayda }\end{array}$ & 0,076 & 0,030 & 0,091 & 2.581 & 0,010 & 0,275 & 3,638 \\
\hline Müşteri Odaklılı̆̆g & 0,365 & 0,027 & 0,412 & 13.784 & 0,000 & 0,384 & 2,607 \\
\hline Güvenilir Finansal İmaj & 0,373 & 0,027 & 0,409 & 13.968 & 0,000 & 0,400 & 2,497 \\
\hline
\end{tabular}




\subsubsection{Modelin Paydaşlara Göre Testi}

Araştırmanın ikincil amacı olan paydaşlara göre bu nedensel etkinin değişip değişmediğini analiz etmek için IBM SPSS Statistics 25 programında veriler paydaş grubu verilerine göre bölünmüştür. Müşteri kategorisinde yer alan paydaşların değerlendirmeleri temel alındığında, değişkenlerin işveren marka imajındaki toplam varyansın \%66,8'ini (Tablo 7) açıkladığı görülmektedir (adjusted $R^{2}=0,668 ; \mathrm{F}=134.201$, df1= 4, p <0,001). Tablo 8'de görüldüğü gibi, VIF değerleri Hair (2010) tarafından önerilen eşik değerlerin altında olduğu için modelde yer alan değişkenler arasında çoklu doğrusallık sorunu olmadığı gibi, ürün ile ilişkili fonksiyonel fayda hariç tüm ilişkiler pozitif yönlü ve istatistiksel olarak anlamlı bulunmuştur. Marka ile ilişkili fonksiyonel fayda $(\beta=0,121)$, algılanan müşteri odaklılı̆̆ $(\beta=0,390)$ ve güvenilir finansal imaj $(\beta=$ $0,390)$ arttıkça işveren marka imajı güçlenmektedir.

Toplumun geneli kategorisinde yer alan paydaşların değerlendirmelerine göre, değişkenler işveren marka imajindaki toplam varyansın \%68,8'ini açıklamaktadır (adjusted $R^{2}=0,688 ; \mathrm{F}=111.993$, df1= 4, $\mathrm{p}<0,001$ ). Tablo 8'de görüldüğü gibi, VIF değerleri Hair (2010) tarafından önerilen eşik değerlerin altında olduğu için modelde yer alan değişkenler arasında çoklu doğrusallık sorunu olmadığı gibi, ürün ve marka ile ilişkili fonksiyonel fayda hariç diğer ilişkiler pozitif yönlü ve istatistiksel olarak anlamlı bulunmuştur. Buna göre algılanan müşteri odaklılığı $(\beta=0,497)$ ve güvenilir finansal imaj $(\beta=0,362)$ arttıkça işveren marka imajı güçlenmektedir.

İşletme çalışanları kategorisinde yer alan paydaşların değerlendirmelerine göre, değişkenler işveren marka imajındaki toplam varyansın \%60,8'ini açıklamaktadır (adjusted $R^{2}=.608 ; \mathrm{F}=69.332$, df1= 4, p < .001). Tablo 8'de görüldüğü gibi, VIF değerleri Hair (2010) tarafından önerilen eşik değerlerin altında olduğu için modelde yer alan değişkenler arasında çoklu doğrusallık sorunu olmadığı gibi, ürün ve marka ile ilişkili fonksiyonel fayda hariç diğer ilişkiler pozitif yönlü ve istatistiksel olarak anlamlı bulunmuştur. Buna göre algılanan müşteri odaklılığı $(\beta=0,429)$ ve güvenilir finansal imaj $(\beta=0,422)$ arttıkça işveren marka imajı güçlenmektedir.

Rakip işletme çalışanları kategorisinde yer alan paydaşların değerlendirmelerine göre ise, değişkenler işveren marka imajındaki toplam varyansın \%65,7'ini açılamaktadır (adjusted $R^{2}=.657 ; \mathrm{F}=66.096, \mathrm{df1}=4, \mathrm{p}$ $<.001)$. Tablo 8'de görüldügü gibi, VIF değerleri Hair (2010) tarafından önerilen eşik değerlerin altında olduğu için modelde yer alan değişkenler arasında çoklu doğrusallık sorunu olmadığı gibi, ürün ve marka ile ilişkili fonksiyonel fayda hariç diğer ilişkiler pozitif yönlü ve istatistiksel olarak anlamlı bulunmuştur. Buna göre algılanan müşteri odaklılığ $(\beta=0,282)$ ve güvenilir finansal imaj $(\beta=0,486)$ arttıkça işveren marka imajı güçlenmektedir.

Tablo 7. Paydaşlara Göre Model Özeti

\section{Model Özetleri ${ }^{a}$}

\begin{tabular}{lccccc} 
Model & $\mathbf{R}$ & $\boldsymbol{R}^{\mathbf{2}}$ & $\begin{array}{c}\text { Düzeltilmiş } \\
\boldsymbol{R}^{\mathbf{2}}\end{array}$ & SE & $\begin{array}{c}\text { Durbin- } \\
\text { Watson }\end{array}$ \\
\hline Müşteri & $0,820^{\mathrm{b}}$ & 0,673 & 0,668 & 0,39271 & 1,805 \\
\hline Toplumun Geneli & $0,833^{\mathrm{b}}$ & 0,695 & 0,688 & 0,38617 & 1,762 \\
\hline İşletme Çalışanı & $0,786^{\mathrm{b}}$ & 0,617 & 0,608 & 0,41780 & 1,759 \\
\hline Rakip İşletme Çalışanları & $0,817^{\mathrm{b}}$ & 0,667 & 0,657 & 0,47520 & 1,864 \\
\hline
\end{tabular}

${ }^{a}$ Bağımlı Değişken: İşveren Marka İmajı ${ }^{b}$ Göstergeler: (Sabit Katsayı), ürün ile ilişkili fonksiyonel fayda, marka ile ilişkili fonksiyonel fayda, müşteri odaklılığı, güvenilir finansal imaj 
Ç. P. Bozoklu 11/2 (2019) 1103-1117

Tablo 8. Paydaşlara Göre Regresyon Analizleri

\section{Katsayılar}

\begin{tabular}{ccc}
\hline $\begin{array}{c}\text { Standartlaştırılmamış } \\
\text { Katsayılar }\end{array}$ & $\begin{array}{c}\text { Standartlaştırılmı } \\
\text { ş Katsayılar }\end{array}$ & $\begin{array}{c}\text { Doğrusallık } \\
\text { İstatistikleri }\end{array}$
\end{tabular}

\begin{tabular}{|c|c|c|c|c|c|c|c|c|}
\hline \multirow{2}{*}{ Model } & & \multirow[b]{2}{*}{$\beta$} & \multirow{2}{*}{ SE } & \multirow{2}{*}{$\beta$} & \multirow{2}{*}{$\mathbf{t}$} & \multicolumn{3}{|c|}{ Toleran } \\
\hline & & & & & & $\mathrm{p}$ & $\mathbf{s}$ & VIF \\
\hline \multirow[t]{5}{*}{ Müşteri } & (Sabit Katsayı) & 0,712 & 0,131 & & 50,437 & 0,000 & & \\
\hline & ÜFF & 0,037 & 0,053 & 0,040 & 0,705 & 0,482 & 0,392 & 2,552 \\
\hline & MFF & 0,096 & 0,047 & 0,121 & 20,031 & 0,043 & 0,354 & 2,826 \\
\hline & $\mathrm{MO}$ & 0,317 & 0,041 & 0,390 & 70,687 & 0,000 & 0,488 & 2,050 \\
\hline & GF & 0,334 & 0,042 & 0,390 & 70,880 & 0,000 & 0,513 & 1,950 \\
\hline \multirow{5}{*}{$\begin{array}{l}\text { Toplum } \\
\text { un } \\
\text { Geneli }\end{array}$} & (Sabit Katsayı) & 0,272 & 0,155 & & 10,759 & 0,080 & & \\
\hline & ÜFF & 0,012 & 0,061 & 0,012 & 0,194 & 0,847 & 0,405 & 2,467 \\
\hline & MFF & 0,073 & 0,054 & 0,091 & 10,346 & 0,180 & 0,342 & 2,920 \\
\hline & $\mathrm{MO}$ & 0,473 & 0,051 & 0,497 & 90,241 & 0,000 & 0,536 & 1,867 \\
\hline & GF & 0,344 & 0,050 & 0,362 & 60,858 & 0,000 & 0,556 & 1,800 \\
\hline \multirow{5}{*}{$\begin{array}{l}\text { İşletme } \\
\text { Çalışanı }\end{array}$} & (Sabit Katsayı) & 0,455 & 0,236 & & 10,926 & 0,056 & & \\
\hline & ÜFF & 0,071 & 0,074 & 0,071 & 0,966 & 0,335 & 0,418 & 2,393 \\
\hline & MFF & $-0,027$ & 0,064 & $-0,029$ & $-0,412$ & 0,681 & 0,455 & 2,196 \\
\hline & $\mathrm{MO}$ & 0,382 & 0,058 & 0,429 & 60,636 & 0,000 & 0,534 & 1,874 \\
\hline & GF & 0,437 & 0,066 & 0,422 & 60,597 & 0,000 & 0,545 & 1,834 \\
\hline \multirow{5}{*}{$\begin{array}{l}\text { Rakip } \\
\text { İşletme } \\
\text { Çalışanı }\end{array}$} & (Sabit Katsayı) & ,719 & 0,161 & & 40,465 & 0,000 & & \\
\hline & ÜFF & $-0,032$ & 0,084 & $-0,036$ & $-0,384$ & 0,701 & 0,290 & 3,454 \\
\hline & MFF & 0,126 & 0,087 & 0,148 & 10,438 & 0,153 & 0,239 & 4,181 \\
\hline & $\mathrm{MO}$ & 0,251 & 0,077 & 0,282 & 30,256 & 0,001 & 0,336 & 2,975 \\
\hline & GF & 0,420 & 0,072 & 0,486 & 50,800 & 0,000 & 0,360 & 2,781 \\
\hline
\end{tabular}

Not: ${ }^{a} B a \breve{g ̆ ı m l ı ~ D e g ̆ i s ̦ e n: ~ I ̇ s ̧ v e r e n ~ M a r k a ~ I ̇ m a j ı ~}$

ÜFF: Ürün ile İlişkili Fonksiyonel Fayda; MFF: Marka ile İlişkili Fonksiyonel Fayda; MO: Müşteri Odaklılı̆̆ı i İi: İyi İşveren; GF: Güvenilir ve Finansal Açıdan Güçlü İşletme 


\section{SONUÇ VE TARTIŞMA}

Günümüzde güçlü bir kurumsal imaj yaratmak özellikle finans sektörde büyük önem kazanmıştır. Bu kapsamda hızla rolü artan işveren markalaşması sadece rekabet avantajı sağlamakla kalmayıp, aynı zamanda işletmelere potansiyel müşterileri ve sektörün en iyi çalışanlarını kendisine çekmesini kolaylaştırmakta, diğer ilgili grupların üzerinde de ilgi uyandırmaktadır. Literatüre göre işveren marka imajının sadece çalışanların olumlu kurumsal algılamalarından değil, aynı zamanda çeşitli paydaş gruplarının hem sunulan ürünlerle ilişkili, hem de algılanan müşteri ilişkileri ve finansal yapısı ile ilgili değerlendirmelerinden etkilendiği görülmektedir. Ancak bu etkiyi araştıran her hangi bir araştırmaya ulaşılamamıştır. Bu doğrultuda bu araştırmanın amacı, ürün ve marka ile ilişkili fonksiyonel faydanın, algılanan müşteri odaklılığın ve güvenilir finansal imajın işveren markalaşması üzerindeki nedensel etkisini analiz etmektir. Ayrıca bu nedensel etkinin ilgili paydaş grubuna göre değişeceği düşünülmüştür.

Araştırmanın sonucunda, genel olarak modelin açıklama gücünün oldukça yüksek olduğu belirlenmiştir. İşveren marka imajı üzerinde marka ile ilişkili fonksiyonel faydanın, müşteri odaklılığının ve güçlü finansal imajın doğrudan pozitif yönlü etkisi tespit edilmiştir. Ancak marka ile ilişkili fonksiyonel faydanın, özellikle marka isminin sunduğu garanti algısının bu etkileşim üzerinde etkisinin oldukça minimal düzeyde olduğu, hatta paydaşlara göre yapılan ikincil analizlerde bu değişkenin sadece müşteriler açısından etkili olduğu tespit edilmiştir. Bu sonuç Schofield ve Breen (2006) ile Rehman ve Afsar'ın (2012) araştırma bulguları ile paralellik göstermektedir. Bu sonucun nedeninin Mortgage krizi sonrasında Bankacılık Düzenleme ve Denetleme Kurumu tarafından geliştirilen ve finansal yapının güvenilirliğini arttıran düzenlemelerin olduğu düşünülmektedir. Tüm bankaların bu değişiklikleri hayati bir zorunluluk olarak uygulaması nedeniyle, özellikle tanınırlığı yüksek olan banka markaları kapsamında, işlemlerin konforu ya da güvenliği açısından bir farklılı̆̆ı olmaması, sundukları garanti algısının ise düşük düzeyde etkili çıkması rasyoneldir.

Bir diğer yandan, algılanan müşteri odaklılığı ve güvenilir finansal imaj kapsamındaki sonuçlar ise oldukça ilgi çekicidir. Güvenilir finansal imajın etkisi göreli olarak algılanan müşteri odaklılığından daha yüksek bulunmuştur. Güçlü ve güvenilir finansal imaj, müşterilerin, çalışanların ve yatırımcıların finansal risk algısını ortadan kaldıracağı için bu kadar önemli çıkması doğal olarak görülmektedir. Özellikle uzun süredir Türkiye'de devam eden ekonomik durgunluk ve kriz ortamı, bankacılık hizmetlerinde güvenilir finansal imajın rolünü perçinlemiştir. 1990lar boyunca ve 200lerin başında kendini gösteren, bankacılık alanındaki en büyük yolsuzluk olarak Türkiye tarihine geçen İmar Bank Skandalı (Yucel ve Adiloglu, 2017) bu beklentinin önemini vurgular niteliktedir. Nitekim, 2017 yılında Halkbankası üst düzey yetkilisi Mehmet Hakan Atilla ile Rıza Zarrab'ın karıştığı skandal ve ABD mahmelerince aldıkları hapis cezaları, itibarın kırılganlığı nedeniyle güçlü bir finansal imajın sürdürülebilirlik açısından katkısını sergilemektedir. Bir diğer yandan, Foscht vd. (2009) yaptıkları araştırmada, özellikle genç pazarı için (15-30 yaş arasındaki kişiler) banka personelinden memnuniyetin oldukça önemli bir etmen olduğunu tespit etmiştir. Banka çalışanlarının özellikle müşteriler ile etkileşim içerisinde olanların müşteri odaklılık algısını doğrudan etkilemesi nedeniyle, bu araştırmanın sonuçları ile benzer olduğu düşünülmektedir.

Bu iki değişkenin farklı paydaş grupları gözündeki yeri incelendiğinde ise, müşteri odaklılığın en çok toplumun algılamasında etkili olduğu, rakip işletme çalışanları açısından ise bu etkini ciddi oranda düştüğü belirlenmiştir. Tersine, güvenilir finansal imaj ise en çok rakip işletme çalışanlarının işveren markalaşması algısını etkilemektedir. Toplumun geneli açısından ise göreli olarak daha az dikkat gösterilmektedir. Sonuçlara göre, sektörel uzmanlığı ya da bilgi birikimi olmayan, potansiyel genç müşteriler diğer paydaş gruplarına kıyasla müşteri odaklı stratejilerine göre başarılı görmektedir. Ayrıca, profesyonel düzeyde deneyimi ve bilgi birikimi olan genç sektör çalışanları ise tercihlerini finansal göstergelere göre yapmaktadır. Bu sonuçlar Y Kuşağı'nın bankacılık hizmetlerini yorumlarken kendi çıkarları ve temel beklentilerine uygun olarak, rasyonel değişkenlere göre değerlendirdiğini de ima etmektedir.

Bu bulgulara göre, bankaların işveren markalaşması çabaları kapsamında, öncelikle odaklanmak istedikleri paydaşları ayrı ayrı ele almaları ve onların beklentilerine bağlı olarak müşteri odaklılığı ya da finansal yapının güvenilirliği üzerine odaklı reklam ve halkla ilişkiler mesajları düzenlemeleri önerilmektedir. 


\section{Ç. P. Bozoklu 11/2 (2019) 1103-1117}

Örneğin bankalar, yeni işe alım dönemlerinden önce hedefledikleri üniversite öğrencilerine yönelik paneller ve çalıştaylar düzenleyerek, işveren markası olarak çalışanlarına sundukları fonksiyonel, ekonomik ve psikolojik faydaları, müşteri odaklılığı kapsamında uyguladıkları politikaları, finansal imajını ve bu sonuçları ortaya çıkartan içsel markalaşma sürecini tanıtabilirler. Böylece örgütsel değerleri ile ilk baştan daha yüksek derecede uyumlu potansiyel sektör çalışanlarına ulaşmaları ve böylece daha verimli ve etkin çalışmaları mümkün olabilir. Benzer şekilde, sektörde uzman deneyimli personele ulaşmak istediklerinde ise, işveren markası olarak çalışanlarına sundukları fonksiyonel, ekonomik ve psikolojik faydaların yanında, güvenilir finansal imajına ilişkin mesajlara odaklanmalıdır. Toplumun geneli gözünde işveren marka imajının güçlendirilmesi için müşteri odaklılığı üzerine odaklanılmalı ancak içsel markalaşma sonucunda yaratılan güvenilir finansal yapıya da vurgu yapılmalıdır. Bu paydaş gruplarından farklı olarak mevcut ve potansiyel müşteriler kapsamında ise, işveren markalaşması kurumsal marka imajını güçlendirecektir. En yoğun çabanın bu kapsamda gösterilmesi gerekmektedir. Bankaların gelecekteki müşterilerini oluşturacak olan Y Kuşağı'nın temel özelliklerine bağlı olarak, yaratıcı reklam stratejileri aracılığı ile sunulan tüm faydalar dijital uygulamalar ve sosyal medya kullanılarak iletilmelidir. İçsel markalaşma süreci temalı reklamlar içerisinde, çalışanlara sunulan fonksiyonel, ekonomik ve psikolojik faydaların, güvenilir finansal yapıya, müşteri odaklılığı kapsamında uygulanan politikalara ve markanın önerdiği fonksiyonel faydaya dönüştürülme süreci anlatılabilir.

$\mathrm{Bu}$ araştırma işveren markalaşması kapsamında önemli bilgiler ortaya koysa da, bir takım kısıtlılıklara sahiptir. Araştırma modeli, bankacılık hizmetlerinde sembolik faydanın etkisinin düşük olacağı varsayıldığı için sadece fonksiyonel fayda boyutlarına göre yapılandırılmıştır. Ancak ürün ile ilişkili değerlendirmelerin etkisinin marka ve imaj ile ilişkili değerlendirmelerden oldukça zayıf olması nedeniyle, statü, sosyal kimlik gibi sembolik faydaların da araştırılması gerektiği düşünülmüştür. Ayrıca, yapılan araştırma sonucunda karar birimi olarak seçilen bankalar arasında işveren markalaşması kapsamında anlamlı bir farklılık bulunmamıştır. Bu sonuçların ve önerilerin marka bilinirliği yüksek bankalar için geçerli olduğu unutulmamalıdır. Gelecekte yürütülecek araştırmaların bu kapsamda geliştirilmesi, işveren markalaşması literatürüne katkı sağlayacaktır.

\section{KAYNAKÇA}

Aaker, D. A. (2008). Strategic market management. John Wiley and Sons.

Al-Hawari, M., and Ward, T. (2006). The effect of automated service quality on Australian banks' financial performance and the mediating role of customer satisfaction. Marketing Intelligence and Planning, 24(2), 127-147.

Ambler, T., and Barrow, S. (1996). The employer brand. Journal of Brand Management, 4(3), 185-206.

Backhaus, K., and Tikoo, S. (2004). Conceptualizing and researching employer branding. Career Development International, 9(5), 501-517.

Bank Negara Malaysia (2008). Annual Report of Bank Negara 2008. Kuala Lumpur, Bank Negara Malaysia.

Barber, F., and Strack, R. (2005). The surprising economics of a "people business". Harvard Business Review, 83(6), 80-90.

Barney, J. (1991). Firm resources and sustained competitive advantage. Journal of Management, 17(1), 99-120.

Barrow, S., and Mosley, R. (2011). The employer brand: Bringing the best of brand management to people at work. John Wiley and Sons.

Berry, L. L. (1995). Relationship marketing of services-growing interest, emerging perspectives. Journal of the Academy of Marketing Science, 23(4), 236-245.

Berthon, P., Ewing, M., and Hah, L. L. (2005). Captivating company: dimensions of attractiveness in employer branding. International Journal of Advertising, 24(2), 151-172.

Bitner, M. J. (1992). Servicescapes: the impact of physical surroundings on customers and employees. Journal of Marketing, 56(2), 57-71. 


\section{Ç. P. Bozoklu 11/2 (2019) 1103-1117}

Bonini, S., Court, D., and Marchi, A. (2009). Rebuilding corporate reputations. McKinsey Quarterly, 3, 75-83.

Carrington, L. (2007). Designs on the dotted line. People Management, 13(21), 36-39.

Cebeci, İ. ve Çabuk, Z. (2016). Tüketicilerin Banka Tercihini Etkileyen Faktörlerin belirlenmesi: Giresun'da Bir Araştırma. Finansal Araştırmalar ve Çalışmalar Dergisi, 8 (14), 57-66.

Cronin, J. J., Brady, M. K., Brand, R. R., Hightower Jr, R., and Shemwell, D. J. (1997). A cross-sectional test of the effect and conceptualization of service value. Journal of Services Marketing, 11(6), 375-391.

Dall'Olmo Riley, F., and De Chernatony, L. (2000). The service brand as relationships builder. British Journal of Management, 11(2), 137-150.

Dowling, G.R. (2006). Communicating corporate reputation through stories. California Management Review, $49,82-100$.

Drucker, P. F. (2002). They're not employees, they're people. Harvard Business Review, 80(2), 70-7.

Dwyer, F. R., and Tanner, J. F. (2002). Business marketing: Connecting strategy, relationships, and learning. New York: McGraw-Hill.

Eggert, A., and Ulaga, W. (2002). Customer perceived value: a substitute for satisfaction in business markets?. Journal of Business and Industrial Marketing, 17(2/3), 107-118.

Filbeck, G., and Preece, D. (2003). Fortune's best 100 companies to work for in America: do they work for shareholders?. Journal of Business Finance and Accounting, 30(5-6), 771-797.

Foscht, T., Schloffer, J., Maloles III, C., and Chia, S. L. (2009). Assessing the outcomes of Generation-Y customers' loyalty. International Journal of Bank Marketing, 27(3), 218-241.

Gatewood, R. D., Gowan, M. A., and Lautenschlager, G. J. (1993). Corporate image, recruitment image and initial job choice decisions. Academy of Management Journal, 36(2), 414-427.

Grewal, D., Monroe, K. B., and Krishnan, R. (1998). The effects of price-comparison advertising on buyers' perceptions of acquisition value, transaction value, and behavioral intentions. Journal of Marketing, 62(2), 46-59.

Grönroos, C. (1997). Value-driven relational marketing: from products to resources and competencies. Journal of Marketing Management, 13(5), 407-419.

Hair, J. F., Black, W. C., and Babin, B. J. (2010). Anderson. RE, 2010. Multivariate Data Analysis. New Jersey, Pearson Prentice Hall.

Hart, S., and Murphy, J. (Eds.). (1998). The new wealth creators. Macmillan.

Hatch, M. J., and Schultz, M. (2001). Are the strategic stars aligned for your corporate brand. Harvard Business Review, 79(2), 128-134.

Heskett, J.L., Sasser, W.E. and Schlesinger, L.A. (1997). The Service Profit Chain: How Leading Companies Link Profit and Growth to Loyalty, Satisfaction and Value. New York: Free Press.

Hoffman, B. J., and Woehr, D. J. (2006). A quantitative review of the relationship between personorganization fit and behavioral outcomes. Journal of Vocational Behavior, 68(3), 389-399.

Hogg, M. K., Cox, A. J., and Keeling, K. (2000). The impact of self-monitoring on image congruence and product/brand evaluation. European Journal of Marketing, 34(5/6), 641-667.

Hunt, S. D. (1976). The nature and scope of marketing. Journal of Marketing, 40(3), 17-28.

Ind, N. (1997). The Corporate Brand. Basingstoke: Macmillan Business.

Ind, N. (1998). An integrated approach to corporate branding. Journal of Brand Management, 5(5), 323-329.

Ismail, I., Haron, H., Nasir Ibrahim, D., and Mohd Isa, S. (2006). Service quality, client satisfaction and loyalty towards audit firms: Perceptions of Malaysian public listed companies. Managerial Auditing Journal, 21(7), 738-756. 


\section{Ç. P. Bozoklu 11/2 (2019) 1103-1117}

Javed, J. (2005). Customer satisfaction at a public sector bank, Karachi. Market Force, 1(2), 48-56.

Kandampully, J., and Duddy, R. (1999). Competitive advantage through anticipation, innovation and relationships. Management Decision, 37(1), 51-56.

Khan, N., and Kadir, S. L. S. A. (2011). The impact of perceived value dimension on satisfaction and behavior intention: Young-adult consumers in banking industry. African Journal of Business Management, 5(11), 4087-4099.

Kuisma, T., Laukkanen, T., and Hiltunen, M. (2007). Mapping the reasons for resistance to Internet banking: A means-end approach. International Journal of Information Management, 27(2), 75-85.

La, K. V., and Kandampully, J. (2004). Market oriented learning and customer value enhancement through service recovery management. Managing Service Quality: An International Journal, 14(5), 390-401.

Lai, C. S., Chiu, C. J., Yang, C. F., and Pai, D. C. (2010). The effects of corporate social responsibility on brand performance: The mediating effect of industrial brand equity and corporate reputation. Journal of Business Ethics, 95(3), 457-469.

Manhnert, K.F. and Torres, A.M. (2007) The brand inside: The factors of failure and success in internal branding. Irish Marketing Review, 19 (1): 54-63.

Martin, G., Beaumont, P., Doig, R., and Pate, J. (2005). Branding: A New Performance Discourse for HR?. European Management Journal, 23(1), 76-88.

Martin, G., and Hetrick, S. (2006). Corporate reputations, branding and people management: A strategic approach to $H R$. Routledge.

McDougall, G. H., and Levesque, T. (2000). Customer satisfaction with services: putting perceived value into the equation. Journal of Services Marketing, 14(5), 392-410.

Minkiewicz, J., Evans, J., Bridson, K., and Mavondo, F. (2011). Corporate image in the leisure services sector. Journal of Services Marketing, 25(3), 190-201.

Moroko, L., and Uncles, M. D. (2008). Characteristics of successful employer brands. Journal of Brand Management, 16(3), 160-175.

Mosley, R. W. (2007). Customer experience, organisational culture and the employer brand. Journal of Brand Management, 15(2), 123-134.

Narver, J. C., and Slater, S. F. (1990). The effect of a market orientation on business profitability. Journal of Marketing, 54(4), 20-35.

Nunnally, J. C., and Bernstein, I. H. (1994) Psychological theory. NY: MacGraw-Hill.

Oly Ndubisi, N., and Kok Wah, C. (2005). Factorial and discriminant analyses of the underpinnings of relationship marketing and customer satisfaction. International Journal of Bank Marketing, 23(7), 542-557.

Patterson, P. G., and Spreng, R. A. (1997). Modelling the relationship between perceived value, satisfaction and repurchase intentions in a business-to-business, services context: an empirical examination. International Journal of Service Industry Management, 8(5), 414-434.

Punjaisri, K., Wilson, A., and Evanschitzky, H. (2008). Exploring the influences of internal branding on employees' brand promise delivery: implications for strengthening customer-brand relationships. Journal of Relationship Marketing, 7(4), 407-424.

Ravald, A., and Grönroos, C. (1996). The value concept and relationship marketing. European Journal of Marketing, 30(2), 19-30.

Rehman, M., and Afsar, B. (2012). Relationship among corporate image, intangible perceived quality, choosing, habit and customer loyalty. Management and Marketing Journal, 10(1).

Rose, C., and Thomsen, S. (2004). The Impact of Corporate Reputation on Performance: Some Danish Evidence. European Management Journal, 22(2), 201-210. 
Ç. P. Bozoklu 11/2 (2019) 1103-1117

Schofield, R. A., and Breen, L. (2006). Suppliers, do you know your customers?. International Journal of Quality and Reliability Management, 23(4), 390-408.

Sweeney, J. C., Soutar, G. N., and Johnson, L. W. (1999). The role of perceived risk in the quality-value relationship: a study in a retail environment. Journal of Retailing, 75(1), 77-105.

Tank, J., and Tyler, K. (2005). UK student banking revisited: influences and the decision-making process. Journal of Financial Services Marketing, 10(2), 152-164.

Türkyılmaz, A., and Özkan, C. (2007). Development of a customer satisfaction index model: An application to the Turkish mobile phone sector. Industrial Management and Data Systems, 107(5), 672-687.

Vázquez, R., Del Rio, A. B., and Iglesias, V. (2002). Consumer-based brand equity: development and validation of a measurement instrument. Journal of Marketing Management, 18(1-2), 27-48.

Vergin, R. C., and Qoronfleh, M. W. (1998). Corporate reputation and the stock market. Business Horizons, 41(1), 19-27.

Walsh, G., and Beatty, S. E. (2007). Customer-based corporate reputation of a service firm: scale development and validation. Journal of The Academy of Marketing Science, 35(1), 127-143.

Woodruff, R.B., and Gardial, F.S. (1996). Know Your Customer: New Approaches to Understanding Customer Value and Satisfaction. Cambridge: Blackwell Publishers.

Yılmaz, V., Çelik, H. E., ve Depren, B. (2007). Devlet ve özel sektör bankalardaki hizmet kalitesinin karşılaştırılması: Eskişehir örneği.

Yucel, G., and Adiloglu, B. (2017). One of the greatest fraud case in the world: The Imar Bank case from Turkey", European Journal of Business and Management, 9(17), 90-96.

Zameer, H., Tara, A., Kausar, U., and Mohsin, A. (2015). Impact of service quality, corporate image and customer satisfaction towards customers' perceived value in the banking sector in Pakistan. International Journal of Bank Marketing, 33(4), 442-456. 